\title{
O KONOTACJACH KOLORYSTYCZNYCH W KULTURZE CHIŃSKIEJ: CZERWONY I ŻÓETY ${ }^{1}$
}

W czasach starożytnych praludność chińska uważała karmazynowy, niebiesko-zielony, żółty, biały i czarny za pięć podstawowych barw² ${ }^{2}$ które zrodziły wszechświat i ziemię.

\footnotetext{
1 Ze względu na ograniczone rozmiary artykułu w kolejnych dwóch zeszytach czasopisma ukażą się dalsze jego części poświęcone kolorom: niebieskiemu, zielonemu i fioletowemu (planowane wydanie „Gdańskie Studia Azji Wschodniej” 2018, z. 14), a także białemu i czarnemu („Gdańskie Studia Azji Wschodniej” 2019, z. 15). Do opracowania niniejszego artykułu wykorzystano następujące publikacje: Yuan Jieying 袁杰英, Zhongguo Lidai Fushi Shi 中国历代服饰史 [Historia ubioru chińskich dynastii]. Gaodeng Jiaoyu Chubanshe, Beijing 1994; E. Schafer 爱德 华·谢弗著, Tangdai de Wailai Wenming 唐代的外来文明 [Obce cywilizacje epoki Tang], Shanxi Shifan Daxue Chubanshe, Xi'an 2005; Zhu Ruimin 朱瑞玟, Xi Jin Qian Hua, Fushi Wenhua be Chengyu 洗尽铅华, 服饰文化与成语 [Wszystkie kolory i emocje zostały zmyte - kultura ubioru a chengyu], Shoudu Shifan Daxue Chubanshe, Beijing 2006; Lin Shuxin 林淑心, Yi Jin Xing 衣锦 行 [Na pokaz], Taiwan Guoli Bowuguan Chubanshe, Taibai 1995; Wang Weidi 王维堤, Zhongguo Fushi Wenhua 中国服饰文化 [Kultura ubioru chińskiego], Shanghai Guji Chubanshe, Shanghai 2009; Wang Xiongfei 王雄飞, Yu Lukui 俞旅葵, Kuangwuse shiyong shouce 矿物色使用手册 [Kolory minerałów - podręcznik], Renmin Meishu Chubanshe, Beijing 2005; Yongtian Taihongjian 永田泰弘监, Se zh hi Shoutie 色之手帖 [Księga Kolorów], Riben Xiaoxueguan Chuban, Tokyo 2004; He Binyu 何丙郁, He Guanbiao 何冠彪 1983. 'Zhongguo Keji shi Gailun' 中国科技史概论 [Wstęp do historii chińskiej nauki i technologii], Xianggang Zhonghua Shuju, Hong Kong 1983; Zhuang Qiushui 庄秋水, Feng ru Luoyi 风入罗衣 [Moda w Luoyi], Wenhui Chubanshe, Shanghai 2009; Ma Dayong 马大勇, Hua Fu Mei Yun 华服美蕴 [Kolekcja piękna chińskiej odzieży], Wenwu Chubanshe, Beijing 2009; Tian Zibing 田自秉, Zhongguo Gongyi Meishu shi 中国工艺美 术史 [Historia chińskiej sztuki i rzemiosła], Dongfang Chuban Zhongxin, Beijing 1985; Zuo Wuzhang, Hua de Liqing Baoyu 花的丽情抱语 [Czuły język kwiatów], cz. 1-2, Yancheng, Jiangsu 2000; Liu Yutang 刘玉堂, Zhang Shuo 张硕, Changjiang Liuyu Fushi Wenhua 长江流域服饰文化 [Kultura ubioru dorzecza rzeki Jangcy], Hubei Jiaoyu Chubanshe, Wuhan 2005; Wang Qianjin 汪 前进, Zhongguo Mingdai Keiji shi, 中国明代科技史 [Historia nauki i technologii chińskiej dynastii Ming], Renmin Chubanshe, Beijing 1994; Huang Renda 黄仁达, Zhongguo Yanse 中国颜色 [Kolory Chin], Dongfang Chubanshe, Beijing 2013.

2 W związku z odmienna percepcją kolorów w tekście zastosowano następujące tłumaczenia nazw barw: 红 (bong) - czerwony, 赤 (chi) - karmazynowy, 朱 (zhu) - cynober, 黄 (buang) - źółty, 土黄色 (tubuangse) - ziemisty żółty, 明黄色 (ming huangse) - jasnożółty, 金黄色 (jin huangse) złoty, 柘黄色 (zhehuangse) - morwowy.
} 
Następnie, zgodnie z regułami teorii pięciu elementów budujących cały wszechświat, tj. ziemi (土 - tu), drewna (木 - mu), ognia (火 - buo), wody (水 - shui) oraz metalu (金 - jinn) wyznaczono pięć kierunków: wschód, południe, zachód, północ i centrum, którym również przypisano określone połączenia kolorystyczne. W barwy wpisano wiele różnorodnych kulturowych koncepcji, związanych m.in. z pozycja władzy, teoriami filozoficznymi, rytuałami oraz wierzeniami. Stopniowo formował się odrębny system kultury kolorystycznej, który stał się ważnym elementem tradycyjnej kultury chińskiej. W niniejszym artykule poddano analizie i deszyfracji różne chińskie konotacje: historyczne, polityczno-ekonomiczne, społeczno-obyczajowe, literacko-artystyczne, związane z tradycyjnymi świętami, jak również ze światopoglądem oraz standardami estetycznymi w odniesieniu do kolorów.

\section{Czerwony $(\text { 红 }- \text { hong })^{3}$}

Chiński znak 红 (hong) pojawił się mniej więcej w epoce brązów, a jego historia liczy ponad 3 tysiące lat. Jednakże dopiero za czasów dynastii Tang (około VII w. n.e.) znak ten faktycznie stał się nazwą własną koloru - szykownej, roziskrzonej czerwieni, której głębsze znaczenie pozostało bez zmian aż do dzisiaj. Jest ona także kolorem najbliższym sercu Chińczyków Han - można powiedzieć, że wzbogaciła chińską historię, płaszczyznę kulturową i ludowo-obyczajową.

$\mathrm{Na}$ Zachodzie kolor czerwony jest kojarzony z niebezpieczeństwem, krwia, ekstremum, zatrzymaniem i pośpiechem, natomiast w Chinach wyraźnie odnosi się do znaczeń zwiazzanych z elementami obyczajowości państwowej i ludowej - rześkością, władza, pozycją, optymizmem, romantyzmem i seksapilem.

Czerwień była modnym kolorem swobodnych czasów tangowskich. Cesarz ówczesnej dynastii na co dzień przywdziewał czerwoną szatę, a oficjele od trzeciej do piątej rangi mieli obowiązek noszenia strojów dworskich właśnie w tym kolorze. Swawolna i gorąca czerwień była wówczas także modną barwą ulubioną przez kobiety. Za czasów dynastii Tang na ślub przywdziewano zazwyczaj niebiesko-zielone szaty, jednak przy ożenku urzędników zezwalano na czerwień. W czasach dynastii Song kobiety wywodzące się z wysokiej warstwy społecznej były uprawnione do noszenia szat cesarskich, a przy ożenku - czerwonej sukni z długimi rękawami. Od tego czasu aż do dnia dzisiejszego para młoda zwyczajowo ma czerwone stroje.

W polityce kolor czerwony symbolizuje władzę i pozycję, a w tradycyjnej teorii pięciu barw wraz z karmazynem wchodzi w skład kolorów podstawowych.

3 Szersze rozważania na temat symboliki czerwieni w kulturze chińskiej zob. Wu Lan, Kultura chińskiego koloru - symbolika czerwieni, „Gdańskie Studia Azji Wschodniej” 2017, z. 12, s. 136-141. 
Z punktu widzenia koncepcji pięciu żywiołów należy do południa, które symbolizuje ogień. Za czasów dynastii Ming ze względu na rozwój kraju na południu w kulturze politycznej promowano właśnie używanie czerwieni wyrażającej ogień. Także nazwisko cesarza Yuanzhanga (1328-1398), który rządził tą częścią kraju, nawiązywało do cynobru. Ówcześni cesarze w trakcie rytualnego składania ofiar przodkom mieli na sobie czerwone szaty, nawet mury miejskie otaczające miasto cesarskie musiały być w tym kolorze. Od tamtego czasu aż do końca panowania dynastii Qing cynober pozostawał specjalnym kolorem wykorzystywanym w architekturze i budowlach związanych z cesarzem. Ponieważ w odległej przeszłości do konstrukcji mostów często używano drewna, a zgodnie ze starożytną teorią pięciu żywiołów z drewna odradza się ogień, na mosty nakładano jasnoczerwoną farbę, co stanowiło odwołanie do tej idei.

Za panowania dynastii Tang dla zwykłych obywateli czerwone pawilony (tzw. bonglou 红楼, lofty z przepięknymi malunkami) były rezydencjami rodzin arystokratycznych. Jednakże kiedy termin ten pojawił się w poezji, nabrał erotycznego znaczenia. Natomiast dystyngowani uczeni nazywali piękną kobietę 'czerwonym obliczem' (红颜 - bongyan), 'czerwonym pyłkiem' (红尘 - bongchen), 'czerwonym rękawem' (红袖 - bongxiu) lub 'czerwoną ozdobą' (红妆 - bongžbuang), a kobiecą sypialnię 'czerwonym pawilonem' (红楼 - bonglou). Czerwień pobudzała wyobraźnię, skłaniała do marzeń i wspomnień.

W tradycyjnej obyczajowości ludowej wszystko, co związane ze świętowaniem, radością, pomyślnością, szczęściem i wrzawą, podkreśla się za pomocą koloru czerwonego. Z okazji Chińskiego Nowego Roku wręcza się czerwone koperty (红包 - hongbao) niosące z sobą życzenie dostatku i szczęścia; zarobienie większej sumy pieniędzy wiąże się z bonusem - tzw. czerwonym profitem (红利 - hongl ). Wyrażenia, takie jak: 'czerwień całej publiczności' (满堂红 - mantanghong), 'wielki, czerwony człowiek' (红人- bongren) czy 'mocna czerwień, mocny fiolet' 大红大 紫 - dahong dazi), symbolizuja sukces; 'ognista czerwień' (火红 - buohong) odnosi się do wrzawy; zaś o człowieku szczęśliwym i rozanielonym mówi się, że jego 'twarz wypełniona jest czerwonym blaskiem' (红光满面 - hongguang manmian). Należy jednak nadmienić, że określenie 'czerwona twarz' (脸红 - lianhong) wyraża też wstyd i zakłopotanie. 'Syndrom czerwonych oczu' (红眼病 - hognyanbing) (w języku chińskim rzeczownik ten nie odnosi się do medycyny) wskazuje na negatywną emocję - zazdrość. We współczesnych ruchach politycznych czerwień jest symbolem postępu, awangardy i świadomości.

Można powiedzieć, że czerwień towarzyszy Chinom od ich początku po dzień dzisiejszy, przeniknęła do głębokich warstw kultury chińskiej. 


\section{Żólty (黄一 buang)}

W języku chińskim znak 黄 (huang) jest tradycyjnym rzeczownikiem określającym kolor, który pierwotnie odnosił się do barwy ziemi. W Shuowen Jiezi (说文解字) jest napisane, że żółty to kolor oświetlanego promieniami słonecznymi pola: 黄部, 地 之色也。(Haungbu, dizhiseye). Natomiast w Shiming (释名·释采昂 - shiming shicai’ang) można wyczytać: „Źółty, błyszczący, oślepiający, jak kolor strugi słonecznej”: 黄, 晃也, 犹晃晃, 像日光色也 (buang, huangye, youbuanghuang, xiang riguang seye), co oznacza, że kolor ten wiązano również z barwą promieni Słońca.

„Przy stworzeniu świata niebo było ciemne, a ziemia żółta” (天地玄黄 - tiandi xuanhuang) - żółty był uznawany przez starożytne ludy chińskie za pierwotną barwę towarzyszącą bezwładnemu mieszaniu się materii, gdy Pangu stwarzał świat. Kolor ten reprezentuje Matkę Ziemię, na której rozmnażają się wszystkie żywe istoty i rozwija się chiński naród. Dlatego też huang tudi (dosł. 'żółta ziemia') był obiektem czci i kultu praludów. W teorii pięciu przemian żółty jest powiązany z ziemią i oznacza początki życia, w odniesieniu do czterech stron świata reprezentuje środek, czyli miejsce symbolizujące najwyższą władzę. W tradycyjnej kulturze chińskiej żółty wiązał się z majestatem, był przypisywany Synowi Niebios i stał się symbolem władzy cesarskiej. Zmiany w monarszej percepcji tego koloru nastapiły dopiero po utworzeniu Republiki Chińskiej w XX w.

Od czasów starożytnych Chińczycy Han stawiali siebie w centralnej (中 - z̧hong) pozycji w odniesieniu do władzy i przestrzeni. Pojęcia 'centralna ziemia' (中土 zhongtu), 'centralna wyżyna' (中原 - zhongyuan) i 'centralne państwo' (中国 - zhongguo, tj. Państwo Środka) reprezentuja geograficzne jądro świata, w którym znajduja się Chiny. Od Okresu Wiosen i Jesieni oraz Walczących Królestw (770-221 r. p.n.e.) po połączeniu tradycyjnej koncepcji pięciu elementarnych kolorów z teorią pięciu żywiołów oraz astrologiczną koncepcją pięciu kierunków uznano, że ziemia zajmuje pozycję centralną i stanowi podstawę wszystkich elementów. Z tego powodu kolor żółty, który jej odpowiada, nazywano 'kolorem ziemi’ (地色 - dise) lub 'kolorem centralnym' (中央之色 - zhognyang ₹̧hise), jest najważniejszy ze wszystkich kolorów podstawowych.

W polityce żółty symbolizował najwyższą władzę, autorytet, ortodoksję i godność. W tradycyjnej kulturze chińskiej miał również inne konotacje, symbolizował światło, a wyrażenie ‘źółty, szczęśliwy dzień’ (黄道吉日 - huangdao jirr) wskazywało na czas pomyślności. Połyskliwe żółte złoto od starożytności należało do bezcennych i rzadko spotykanych metali. Ze względu na fakt, że Chińczycy przez długi czas posługiwali się żółtymi monetami z brązu, ich odcień stał się archetypowym i najpopularniejszym kolorem pieniądza.

Źółty jest uznawany za jeden z najdawniejszych chińskich pigmentów używanych do farbowania materiałów i w malarstwie; ten pozyskiwany z owoców garde- 
nii jaśminowatej był prawdopodobnie najwcześniej wykorzystywanym barwnikiem ubrań. W tradycyjnym malarstwie chińskim zastosowanie mają różnego rodzaju żółte materiały pochodzenia roślinnego i mineralnego, m.in. gumiguta, aurypigment, realgar czy masykot. Pobierany z nich kolor wykorzystywano w dużych ilościach w jaskiniach Dunhuang (敦煌) w prowincji Gansu oraz na freskach z dynastii Tang. W starożytności modne było malowanie przez kobiety na czole pomiędzy brwiami żółtego znaku. Natomiast żółty makijaż na twarzach śpiewaków opery pekińskiej symbolizował odwagę, siłę i gwałtowność.

Tradycyjnie określenie 'czysta żółć' (澄黄 - cheng huang) odnosi się do odcienia, jaki przybiera dojrzały owoc o słodkim zapachu. 'Okres żółtych śliwek' (梅子黄 熟 - meiæi huangshu) odnosi się do radosnego czasu między końcem wiosny a początkiem lata, kiedy owoce te żółkną z dojrzałości. Żółć towarzysząca wegetacji roślin to kolor nadający barwy zmianom między porami roku, symbolizujący 'szelest samotności' (萧瑟落寞 - suse luomo) natury. Jest też barwą jesiennych smutków, symbolem przemijania i ulotności czasu.

W języku chińskim żółty kojarzy się również z dziecinnością - na niemowlęta metaforycznie mówi się ‘źółte usta' (黄口 - buang kou), a na młode lekkomyślne kobiety - 'dziewuchy z żółtymi włosami' (黄毛Y头 - buangmao yatou). Wyrażenie 'dziewczyna żółtego kwiatu' (黄花闺女 - buanghua guinvu) oznacza pannę. Jednak w starożytności żółte włosy kojarzono także z ludźmi w podeszłym wieku: „Na początku starości włosy człowieka zmieniaja się w białe, a jak już będzie za stary w żółte” (人初老则发白, 太老则发黄 - ren chulao ze fabai, tailao že fa haung) ${ }^{4}$.

W czasach współczesnych wraz z przenikaniem kultury zachodniej pojawiły się też negatywne, niewyrafinowane konotacje koloru żółtego związane z seksem, takie jak: 'żółty żart' (黄色笑话 - buangsexiaohua), 'źółte książki' (黄色书籍 - buangseshuji) czy 'żółte informacje' (黄色新闻 - buangse xinwen). Są one jednak sprzeczne z poważnym, patetycznym i pozytywnym kulturowym wydźwiękiem tej barwy wykształconym przez Chińczyków Han.

Kolor ten otacza nas w codziennym życiu, a wśród najbardziej popularnych jego odcieni można wyróżnić ziemisty, jasnożółty oraz złoty. Choć wszystkie one wywodzą się z żółtego, to w chińskiej kulturze mają różną symbolikę.

\section{Ziemisty żółty}

Kolor ziemisty odnosi się do barwy luźnego piasku i skał okruchowych zawierajacych wapń, magnez, potas i inne pierwiastki, jak również do suchego lądu Chin kontynentalnych oraz barw piaszczystej wyżyny lessowej. Był to jeden z pierwszych naturalnych kolorów, z jakim zetknęli się ludzie pierwotni. Jedną z przyczyn uznawania barwy lessu za króla kolorów można odczytać ze starego chińskiego powiedzenia:

4 Wu Jingzi, (Rulin Waishi 儒林外史) [Uczeni], Dongfang Chubnashe, Beijing 1997, rozdz. 31. 
„Żółty zrodził ying (阴) i yang (阳)”. Kolor ten zajmuje dokładnie centralną pozycję, symbolizuje legitymizm i nadrzędność. Często wiąże się go z prostym, prymitywnym charakterem ludzi pracujących fizycznie. Powiedzenie: „Twarz do ziemi, plecy do nieba” (面朝黄土 - mianchao buangtu, 背朝天 - beichao tian) podkreśla właśnie te cechy robotników (zwłaszcza rolników) chińskich. Jednocześnie ziemista żółć odnosi się również do pierwotnej męskiej siły.

Kolor ten należy do najwcześniej umiłowanych przez lud chiński naturalnych barw monochromatycznych, uważa się go również za podstawowy kolor ziemi powstałej po uformowaniu świata z pierwotnego chaosu. Od zarania dziejów koncepcja geograficzna Chińczyków Han wyrażała się w powiedzeniu: „Wysokie niebo, gruba ziemia” (天高地厚 - tiangao dihou), podkreślając wielki szacunek zarówno dla nieba, jak i dla ziemi.

\section{Jasnożółty}

Jasnożólty należy do barw czystych i zimnych, ma w sobie domieszkę zieleni, daje uczucie rześkości i energii. Za panowania dynastii Qing był wykorzystywany jako kolor strojów cesarskich. Jednak pierwszym cesarzem, który nosił zółte szaty, był Yang Jian $z$ dynastii Sui (VI w. n.e.). Od tamtej pory kolejni monarchowie, podażając za zwyczajem poprzedników, wybrali żółty jako uprzywilejowany kolor szat cesarskich. Zapisek o tym odnajdujemy w Du Tong Jian Lun (读通鉴论). Od epoki tangowskiej pod groźbą kary śmierci wprowadzono zakaz noszenia żółtych szat przez poddanych. W 1644 r. do władzy nad Centralną Równiną doszli Mandżurowie, jednak po utworzeniu dynastii Qing mandżurski cesarz nadal promował i darzył ogromnym szacunkiem kulturę Chińczyków Han, praktykowano tradycyjna hanowską koncepcję pięciu kolorów i teorie kolorystyczne, uznając żółty za nadrzędny wśród kolorów podstawowych i potwierdzono jego znaczenie w odniesieniu do legitymizacji władzy. Tym samym źółte szaty nadal pozostały przypisane cesarzowi. Jednak używany do tej pory przez przeszło tysiąc lat odcień morowy strojów cesarskich, m.in. tzw. smoczej szaty (龙袍 - longpao) czy szat pomyślności (吉服 - jif $f$ ), zmieniono na jasnożółty. Z jedwabnej tkaniny w tym odcieniu szyto również szatę cesarzowej. Cesarską żółtą kamizelkę (黄袍 - buangpao) uszytą z jasnożółtego muślinu lub satyny uznawano za najwyższa nagrodę cesarską - zaszczytu jej noszenia dostępowali tylko członkowie rodziny królewskiej, szczycący się osiagnięciami oficjele cywilni i wojskowi oraz specjalni wysłannicy dworscy. Noszenie kamizelki przez zwykłych ludzi było surowo wzbronione, a tych, którzy się tego dopuścili, uznawano za wywrotowców i skazywano na śmierć.

Jasnożółty był dedykowany strojom dynastii Qing przez ponad dwieście lat. Po upadku cesarstwa i ustanowieniu Republiki Chińskiej w 1911 r., wraz ze zmianami epokowymi związanymi z myślą i kolorystyką feudalną barwa ta zaczęła stopniowo blaknąć - powróciła do ludu, który mógł z niej swobodnie korzystać. 
Kolor złoty jest rodzajem barwy ciepłej charakteryzującej się metalowym połyskiem i nutką czerwieni. „Metal: metal ma pięć kolorów, w których przoduje żółty”: (金: 五色金也, 黄为之长 - Jin: wuse jin ye, huang wei zhichang) ${ }^{5}$. Wspomnianych pięć kolorów odnosi się do żółtego złota, białego srebra, karmazynowej miedzi, niebiesko-zielonego ołowiu i czarnego żelaza, które są uznawane za pięć tradycyjnych metali. Już od starożytności kolor złoty kojarzył się z bogactwem, wspaniałością, splendorem, dostatkiem, władzą i religia.

Według starożytnej chińskiej legendy pomarańczowe palące słońce zamieniło się w złotego ptaka. W dawnych czasach taoistyczni alchemicy wierzyli, że jedzenie i używanie złota może prowadzić do nieśmiertelności. Sporządzający eliksiry w pierwszej kolejności pobierali złoto z cynobru, a następnie przekształcali je na błyszczące naczynia, których używali podczas spożywania posiłków - tym sposobem mogli osiagnać życie wieczne. Han Wudi (汉武帝) (141-87 r. p.n.e.) głęboko wierzył w te metody i powierzał stosowanie ich alchemikom. Zapiski dotyczące tych praktyk są najstarszą poświadczoną informacją o użyciu złota w celu wyprodukowania eliksiru nieśmiertelności.

Zastosowanie złota w strojach wiązało się przede wszystkim z rozprzestrzenianiem się kultury królestw zachodnich oraz buddyzmu indyjskiego. Wśród wartościowych produktów, które w starożytnych czasach dotarły z różnych zachodnich krajów do Chin, na pierwszym miejscu znalazły się przede wszystkim złoto, srebro, klejnoty oraz zwierzęta. Nieoceniony był również wpływ buddyzmu - złoto jest uznawane za najważniejszy z siedmiu skarbów buddyzmu indyjskiego. W sanskrycie występuje pod nazwą Karnasuvarna, co w dosłownym tłumaczeniu oznacza 'wspaniały kolor' (妙色 - miaose) lub 'dobry kolor' (好色 - haose). U klasyków buddyjskich czytamy, że złoto 'nie zmienia swojego koloru' (色无变 - se wu bian), 'nie ma skażonej struktury' (体无染 - ti wu ran), 'sprawia, że ludzie się bogacą' (令人富 - ling ren fu) i 'bez problemu można je formować' (转作无碍 - zhuan zuo wu ai). Cechy te korespondują z czterema cnotami dharmy, którymi sa: stałość (常 - chang), czystość (净 - jing), radość (乐 - le) i ja (我 - wo), dlatego też w buddyzmie czci się kolor złoty. Pofarbowane na złoto buddyjskie świątynie są nazywane 'złotymi miejscami' (金刹 - jinsha), a posagi Buddy 'złotymi ciałami' (金身 - jinshen). Mówi się, że Budda w trakcie przemienienia wypuszcza naraz dziesięć tysięcy wspaniałych złocistych promieni. W świątyniach często jest on przedstawiany na złotym liściu. Słowa wymawiane w Sutrze prayczynn i skutkón wyjaśniają, dlaczego posagi Buddy maluje się złotym kolorem:

5 Chen Zhen, 宋史 Songshi [Traktat o ubiorze] [w:] 舆服志 Xingfurhi [Historia dynastii Song], Shanghai Renmin Chubanshe, Shanghai 2003. 


\section{Dlaczego nasze teraźniejsze życie jest drogocenne? \\ Bo w poprzednim zdobiliśmy Buddę wszelkimi bogactwami. \\ (生富贵是何因? sheng fugui shi he yin? \\ 前世舍财装佛金 qianshi shecai zhuang fojin)}

Ten religijny aspekt pogłębił uwielbienie i popularność koloru złotego wśród Chińczyków Han.

Kwitnąca epoka tangowska rozpoczęła czasy chwały i splendoru złota - złoty kurz był wówczas używany jako farba do malowideł w jaskiniach Dunhuang. W tamtych czasach przykładano szczególną wagę do wyglądu, ozdób, pięknego stroju - od fascynatorów i biżuterii, poprzez buty, aż po odzież wyszywaną złotą nitką - wszystkie te elementy zachwycały złocistym blaskiem. Moda na ekstrawagancję spotkała się z krytyka za czasów dynastii Song - w 1014 r. Song Zhenzong wydał Traktat o ubiorze 《宋史 - Songshi》, na mocy którego wprowadzał zakaz używania złotych ozdób przez lud. Czytamy w nim: „W 7 roku trzeciej ery panowania zakazuje się ludowi zakładania złota” (大中祥符七年, 禁民间服锁金 - Dažbong xiangfu qi nian, jin mingjianfu suo jin $)^{6}$. Cesarz zamierzał w ten sposób skłonić społeczeństwo, by powróciło do prostego i skromnego trybu życia. Jednakowoż mimo zakazu moda na złoto, które początkowo symbolizowało bogactwo i splendor, przetrwała aż do dnia dzisiejszego, co może stanowić dowód na niezmienność stanowiska względem trendów i dobrobytu.

\section{Podsumowanie}

Czerwień była modnym kolorem swobodnych czasów tangowskich. W chińskiej polityce kolor ten symbolizuje władzę i pozycję, a w tradycyjnej teorii pięciu barw wraz z karmazynem wchodzi w skład kolorów podstawowych. Z punktu widzenia koncepcji pięciu żywiołów należy do południa, które symbolizuje ogień. Za czasów dynastii Ming ze względu na rozwój kraju na południu w kulturze politycznej promowano właśnie używanie czerwieni wyrażającej ogień. Kolor żółty ziemisty odnosi się do barwy luźnego piasku i skał okruchowych zawierających wapń, magnez, potas i inne pierwiastki, jak również do suchego lądu Chin kontynentalnych oraz barw piaszczystej wyżyny lessowej. Był to jeden z pierwszych naturalnych kolorów, z jakim zetknęli się ludzie pierwotni.

6 Ibidem. 


\section{SUMMARY}

\section{COLOUR CONNOTATIONS IN CHINESE CULTURE: RED AND YELLOW}

Ancient peoples of China considered crimson, blue-green, yellow, white and back to be the five primary colours that gave rise to the universe and Earth. Then, according to the theory of Five Elements that make up the universe, i.e. Earth $($ 土 $-t u)$, Wood $($ 木 $-m u)$, Fire (火 - buo), Water (水 - shui) and Metal (金 - jin), five directions were set: East, South, West, North and Centre to which specific colour combinations were assigned. The colours implied a number of diverse cultural concepts associated with, e.g. role of power, philosophical theories, rituals and beliefs. Gradually a new colour system came into being and became an important value in traditional Chinese culture. This article looks at the meaning of red (红 - bong) and yellow (黄 - buang) and their shades, i.e. earthy yellow, light yellow and golden. 